\title{
Effect of Parenteral Vaccination of Newborn Holstein Calves against Viral Agents Involved in Bovine Respiratory Disease (BRD)
}

\author{
Viviani Gomes ${ }^{1}$, Diego Daniel Gonzalez², Karina Medici Madureira33, \\ Marina Valeria Mozgovoj' ${ }^{2}$, Camila Costa Baccili', Bruno Toledo Silva', \\ Jean Silva Ramos', Karen Nascimento Silva' \& Edviges Maristella Pituco ${ }^{4}$
}

\begin{abstract}
Background: Newborn calves are born immunosuppressed, hypogammaglobulinemic, immunologically immature, and therefore more vulnerable to many infectious diseases. During pregnancy, the fetal-placental environment is regulated by Th2-type cytokines that neutralize Th1 responses, an important factor for immune defense against viral agents. The ingestion and absorption of colostral immunoglobulins enhance the immunity of the neonate. However, the presence of maternal antibodies might negatively affect the success of parental vaccination in the first two months of life. This study aimed to evaluate the effecacy of parenteral vaccination in newborn calves with high titers of maternal antibodies against respiratory viruses.

Materials, Methods \& Results: Twenty-eight Holstein calves were allocated to the vaccinated group (VAC, $\mathrm{n}=18)$ or an unvaccinated control group (NVAC, $\mathrm{n}=10$ ). The initial vaccination with $5 \mathrm{~mL}$ of a commercial vaccine occurred around the 14th day of life (D14) and the booster at D35. Respiratory and diarrhea symptoms were evaluated at D12, D14, D16, D20, D31, D36, D45, D53, and D60. Blood samples were taken for leukogram, haptoglobin, and seroneutralization of BVDV, BoHV-1, BRSV, and BPI3V, at the time of vaccination at D14 (T1), at booster (D35, T2), and 21 days after the booster (D56, T3). Despite the increased prevalence of BRD during the period of the study, no calves from either group exhibited respiratory disease at D12 or D14. In subsequent assessments, the frequency of BRD increased over time in the VAC group until it reached a maximum prevalence of 38.9\% (7/18) at D31. In the NVAC group, the maximum prevalence observed was $40 \%$ at D45 and D60. A comparison of the frequencies for BRD cases showed a statistical trend at D36 $(P=0.07)$, with a higher prevalence for the NVAC group (30\%) in relation to the VAC group (5.6\%). For the NVAC group, a greater number of total leukocytes was observed at T3 $(P=0.038)$ and granulocytes (trend) at T2 $(P=0.066)$. Time analysis demonstrated a decrease in haptoglobin concentration in both groups (NVAC, $P=0.005$ and VAC, $P=0.006$ ), with a reduction in the values at $\mathrm{T} 1$ and $\mathrm{T} 3(\mathrm{NVAC}=0.005$ and $\mathrm{VAC}=0.024)$. Antibody titers were similar between groups for BVDV, BoHV-1, and BRSV. Higher titers for BPI3V were observed for the VAC group at D56 $(P=0.045)$.

Discussion: The early-onset BRD was present in both groups between 30 and 60 days of age, based on the higher prevalence observed. These data reinforce the importance of early immunization programmes before infection. Factors such as management practices and facilities may have also contributed to the higher prevalence of BRD. The increased number of leukocytes and neutrophils at T2 (D35) and T3 (D56) in the NVAC group points to a stronger inflammatory response to various types of potential challenges. The inflammatory leukocyte profile explains the higher haptoglobin values observed in the NVAC group at T2 (D35). The similarity of titers of antibodies against BVDV, BoHV-1, and BRSV between groups may indicate that vaccinating the calves at 14 days of age did not induce a humoral immune response to these viruses, likely due to interference from the maternal antibodies. Early vaccination prevented a drop in specific viral antibodies and promoted partial protection for vaccinated calves around 14 days of age, with a decrease in the intensity of the inflammatory response at the peak of the disease and a higher concentration of antibodies against BPI3V after the booster.
\end{abstract}

Keywords: bronchopneumonia, colostrum, maternal antibodies. 


\section{INTRODUCTION}

Newborn calves are susceptible to antigenic challenges after birth as they are born hypogammaglobulinemic and immunologically immature [9]. During pregnancy, the fetal-placental environment is regulated by Th2-type cytokines that neutralize Th1 responses, an important factor for immune defense against viral agents [5]. Temporary protection of newborns against respiratory viruses is enhanced by ingestion and absorption of colostrum containing immunoglobulins (Igs) responsible for the neutralization and elimination of the pathogen before it reaches the organs $[8,20]$. The maximum frequency of bovine respiratory disease (BRD) in heifers aged between 30 and 40 days is an indication of reduction of maternal antibodies and need for the establishment of early immunization protocols for prevention of BRD [14].

Vaccine-induced immune responses in newborns might be suppressed by maternal antibodies in the first two months of life $[6,22]$. Antibodies titers against BRD do not increase after early vaccination of calves, but this protocol can induce cellular response and immunological memory $[7,17]$.

Nowadays, approximately nine parenteral and one intranasal vaccines against BRD are registered in Brazil [3] and most formulations contain aluminum hydroxide as adjuvant, which predominantly induces humoral immune response. Studies about effectiveness of protocols of vaccination are very scarce. This scenario is aggravated when applied to the calf rearing system. The aim of this study was to evaluate the effecacy of parenteral vaccination in newborn Holstein calves with high titers of maternal antibodies against respiratory viruses.

\section{MATERIALS AND METHODS}

\section{Sampling}

The study was carried out between 2016 and 2017 and conducted on a high production dairy farm, with an average of 70,000 L of milk/day, located in the west region of the state of São Paulo $\left(22^{\circ} 10^{\prime} \mathrm{S}\right.$, $\left.47^{\circ} 15^{\prime} \mathrm{W}\right)$, Brazil.

\section{Vaccination protocol}

Colostrum donor cows underwent vaccination protocols established in the farm's health calendar. The first vaccination started at 60 days of age, followed by booster at 90 days of age and semestral revaccinations, carried out in April and October. The farm used the commercial vaccine ${ }^{1}$ containing inactivated type
1 (5960) and type 2 (53637) BVDV strains; BoHV-1 (Cooper) and BPI3V (RLB 103) live/thermosensitive; BRSV (375) live/attenuated; Leptospira canicola, L. grippotyphosa, L. hardjo, L. icterohaemorrhagiae and L. pomona inactivated, associated with Quil A, cholesterol and Amphigen as adjuvants.

\section{Management}

Management adopted for the assistance to newborn calves was followed according to the farm protocol. Calvings were assisted and calves were immediately separated from their mothers. Colostrum screening was performed after the first milking with the use of a colostrometer and reference value for an IgG concentration $\geq 5,000 \mathrm{mg} / \mathrm{dL}$. The first feeding of fresh colostrum ( $3 \mathrm{~L}$ ) was offered in a bottle between birth and the $1^{\text {st }}$ two hours of life, the second feeding was offered at $6 \mathrm{~h}$ of age, with a volume ranging from 2 to $3 \mathrm{~L}$, depending on the cow's production. After colostrum, heifers were suckled with $6 \mathrm{~L}$ of milk/ day, commercial ration, and water ad libitum until the weaning period $(\approx 70$ days of age).

\section{Experimental design}

During the experimental period, calves were kept in individual suspended cages $\left(1.2 \mathrm{~m}^{2}\right)$, distributed in a covered and ventilated shed with an area of 112.5 $\mathrm{m}^{2}$ and height of $4.5 \mathrm{~m}\left(1.18 \mathrm{unit} / \mathrm{m}^{2}\right)$, used exclusively for this work to prevent the contact of the calves in this research, considering that the farm used live intranasal vaccine containing BRSV, BPI3V, and BoHV-1.

Holstein calves $(n=28)$ were selected for field research, randomly distributed into 2 experimental groups: VAC group - animals vaccinated between 11-22 days of age and revaccinated between 32-43 days ( $\mathrm{n}=$ 18); and NVAC group - unvaccinated control animals (n $=10$ ). A volume of $5 \mathrm{~mL}$ of a commercial vaccine ${ }^{1}$ was applied subcutaneously in the region of the neck. Scores for BRD and diarrhea were evaluated at ages of (days) D12, D14, D16, D20, D31, D36, D45, D53, and D60.

Blood samples from the calves were obtained for leukogram (tubes containing EDTA), haptoglobin and seroneutralization (tubes without anticoagulant) at the vaccination day (T1-11 at 22 days), booster (T2-32 at 43 days), and 21 days after the $2^{\text {nd }}$ dose of the vaccine (T3-53 at 64 days), by puncture of jugular vein. Aliquots were frozen at $-80^{\circ} \mathrm{C}$.

Calves were submitted to clinical evaluation before the application of the $1^{\text {st }}$ dose of the vaccine (D14), 
21 days after the $1^{\text {st }}$ dose (D35), and 21 days after the $2^{\text {nd }}$ dose (D56). Respiratory disease was monitored according Poulsen \& McGuirk [18] and the sum of scores $\geq 5.0$ was considered positive for respiratory disease.

Total and differential count of leukocytes were determined in an automatic device ${ }^{2}$ and serum haptoglobin (Hp) concentration was assessed according Jones and Mould [12]. Titers of specific antibodies for the respiratory viruses (BVDV, BoHV-1, BRSV, BPI3V) were evaluated by the seroneutralization (SN) technique according to the manual established by OIE [16].

Specific cellular immune response against respiratory viruses was assessed by analyzing the proliferation of mononuclear blood cells (MN). Mononuclear blood cells isolation was performed according to Novo et al. [15] followed by adjusting the cell concentration to $5 \times 10^{6} / \mathrm{mL}$.

\section{Statistical analysis}

The program SPSS version 18 was used. Data normality was tested with Shapiro-Wilk and the set of non-parametric data was submitted to logarithmic, inverse, and quadratic root transformation until parameterization. Titers of antibodies against BVDV-1, BoHV-1, $\mathrm{BRSV}$, and BPI3V maintained non-parametric distribution and were therefore compared between groups by the Mann-Whitney test, and between times by Friedman test associated with the Wilcoxon test. Parametric quantitative variables were compared between groups and times simultaneously by the 2-way ANOVA and post hoc Bonferroni tests. The association between the frequencies (\%) of BRD and experimental groups was determined by the Chi-square test and Fisher's test.

\section{RESULTS}

Considering the prevalence of BRD, only calves serum negative for BRD were included in both experimental groups (D12-14). The frequency increased over time in the VAC group (D16: 9.1\%, 1/11; D20: $6.3 \%, 1 / 16)$ until it reaches the maximum prevalence of $38.9 \%(7 / 18)$ at D31. In the following moments, the prevalences were: D36 (5.6\%, 1/18); D45 $(23.5 \%, 4 / 17)$; D53 (33.3\%, 6/18), and D60 (17.6\%, $3 / 17)$. In the NVAC group, the maximum prevalence observed was $40 \%$ at D45 and D60, and in the moments D16, D20, D31, D36, and D53 the frequencies were respectively: $0 \%(0 / 7) ; 22.2 \%(2 / 9) ; 20.0 \%(2 / 10)$; $30.0 \%(3 / 10)$, and $30.0 \%$ (3/10). The comparison of the BRD frequencies between groups revealed a statistical trend at D36 $(P=0.07)$, with a higher prevalence in the NVAC (30\%) in relation to VAC group (5.6\%).

Means and standard deviations of leukogram and $\mathrm{Hp}$ are shown in Table 1. The absolute number $\left(\mathrm{x} 10^{3} / \mu \mathrm{L}\right)$ of total leukocytes was higher in NVAC group at T2 $(P=0.089)$ and T3 $(P=0.038)$, with a tendency to a greater number of granulocytes in T2 $(P=0.066)$.

Table 1. Mean values and standard deviations of the leukogram and serum haptoglobin of vaccinated (VAC) and non-vaccinated (NVAC) Holstein calves against respiratory virus from 11 to 64 days of life.

\begin{tabular}{|c|c|c|c|c|c|}
\hline Parameter & Group & $\mathrm{T} 1$ & $\mathrm{~T} 2$ & $\mathrm{~T} 3$ & $P$ \\
\hline \multirow{2}{*}{ Leukocytes } & NVAC & $10.3 \pm 3.19$ & $7.86 \pm 2.6$ & $8.68 \pm 2.55$ & 0.195 \\
\hline & VAC & $8.7 \pm 2.93^{\mathrm{a}}$ & $6.11 \pm 2.45^{b}$ & $6.7 \pm 2.02^{\mathrm{ab}}$ & 0.005 \\
\hline$P$ & - & 0.211 & 0.089 & 0.038 & - \\
\hline \multirow{2}{*}{ Granulocytes } & NVAC & $7.06 \pm 2.69$ & $4.6 \pm 2.47$ & $4.29 \pm 2.22$ & 0.051 \\
\hline & VAC & $5.63 \pm 2.24^{\mathrm{a}}$ & $3.11 \pm 1.37^{b}$ & $3.06 \pm 1.22^{b}$ & 0.000 \\
\hline$P$ & - & 0.166 & 0.066 & 0.122 & - \\
\hline \multirow{2}{*}{ Lymphocytes } & NVAC & $2.21 \pm 0.8^{\mathrm{b}}$ & $2.4 \pm 0.79^{\mathrm{ab}}$ & $3.31 \pm 0.95^{\mathrm{a}}$ & 0.019 \\
\hline & VAC & $2.20 \pm 1.01$ & $2.31 \pm 1.28$ & $2.81 \pm 1.48$ & 0.310 \\
\hline$P$ & - & 0.939 & 0.677 & 0.234 & - \\
\hline \multirow{2}{*}{ Monocytes } & NVAC & $1.03 \pm 0.34$ & $0.78 \pm 0.28$ & $0.93 \pm 0.31$ & 0.234 \\
\hline & VAC & $0.91 \pm 0.39$ & $0.76 \pm 0.25$ & $0.79 \pm 0.19$ & 0.316 \\
\hline$P$ & - & 0.173 & 0.765 & 0.165 & - \\
\hline \multirow{2}{*}{$\mathrm{Hp}(\mathrm{mg} / \mathrm{dL})$} & NVAC & $2.38 \pm 1.87^{\mathrm{ab}}$ & $3.2 \pm 5.48^{a}$ & $0.98 \pm 0.25^{b}$ & 0.005 \\
\hline & VAC & $1.46 \pm 0.23^{\mathrm{ab}}$ & $1.54 \pm 0.39^{\mathrm{a}}$ & $1.4 \pm 0.9^{\mathrm{b}}$ & 0.006 \\
\hline$P$ & - & 0.297 & 0.687 & 0.176 & - \\
\hline
\end{tabular}

T= times; $\mathrm{T} 1=11-22$ days; $\mathrm{T} 2=32-43$ days; T3= 53-64 days. $P$ (row)= comparison between groups; $P($ column $)=$ comparison between times. Analysis between groups and times was performed using the 2-way ANOVA test. Different lowercase letters on the same line indicate differences between the moments by the Bonferroni test. Significance was considered when $P \leq 0.05$. 
Analysis of variance over time in each group detected significant variations for leukocyte values only in the VAC group between $\mathrm{T} 1$ and $\mathrm{T} 3(\mathrm{NVAC}=0.195$; $\mathrm{VAC}=0.005)$. Multiple comparisons between times revealed a decrease in total leukocytes between $\mathrm{T} 1$ and $\mathrm{T} 2(P=0.005)$, with similar values between $\mathrm{T} 2$ and $\mathrm{T} 3$ $(P \geq 0.05)$. The absolute number of granulocytes was also affected by time in the VAC group $(P=0.001)$, with a decrease between T1 and T2 $(P=0.001)$ and between T1 and T3 $(P=0.001)$. In contrast, the absolute number of lymphocytes was affected by time only in the NVAC group $(P=0.019)$ with an increase in the number of cells between T1 and T3 $(P=0.02)$. The absolute values of monocytes did not change over time in the NVAC $(P=0.234)$ and VAC group $(P=0.316)$.

Haptoglobin showed a similar value between groups throughout the study $(P \geq 0.176)$. Time analysis by two-way ANOVA with post hoc Bonferroni demonstrated a decrease in Hp concentration in both groups (NVAC, $P=0.005$ and VAC, $P=0.006$ ), with a reduction in the values obtained in $\mathrm{T} 1$ and $\mathrm{T} 3$ (NVAC $=0.005$ and $\mathrm{VAC}=0.024$ ).

Antibody titers obtained for the respiratory viruses are shown in Table 2. The comparison of the antibodies titers between groups showed differences only for titers of BPI3V in T3, with higher values in the VAC group $(P=0.045)$. The dynamic over time revealed constant values for antibody titers against BVDV in the NVAC from T1 to T3 $(P=0.417)$. On the other hand, VAC calves showed variations in the titers of antibodies over time $(P=0.011)$, with a maximum value in T2, which differed from the titer in T3 $(P=$ 0.049). The peak of antibody titer against BVDV at T2 can be explained by the seroconversion of two calves $(20 \%, 2 / 10)$ from NVAC and three calves from the VAC group (16.66\%, 3/18).

Table 2. Neutralizing antibodies, mean values and standard deviations of the proliferation of mononuclear cells stimulated with ConA and viral strains involved in BRD in vaccinated (VAC) and unvaccinated (NVAC) Holstein calves against respiratory virus, from 11 to 64 days of life.

\begin{tabular}{|c|c|c|c|c|c|c|}
\hline Test & Stimuli & Group & $\begin{array}{c}\mathrm{T} 1 \\
(11-22 \text { days })\end{array}$ & $\begin{array}{c}\mathrm{T} 2 \\
(32-43 \text { days) }\end{array}$ & $\begin{array}{c}\mathrm{T} 3 \\
\text { (53-64 days) }\end{array}$ & $P$ \\
\hline \multirow{8}{*}{ 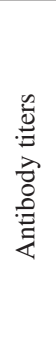 } & \multirow{2}{*}{ BVDV-1 } & NVAC & $6.31(3.32-9.3)$ & $7.8(6.31-8.30)$ & $6.31(5.31-8.3)$ & 0.417 \\
\hline & & VAC & $7.30(0.0-9.3)^{\mathrm{ab}}$ & $8.3(6.31-10.2)^{\mathrm{a}}$ & $7.3(5.3-9.3)^{\mathrm{b}}$ & 0.011 \\
\hline & \multirow{2}{*}{ BoHV-1 } & NVAC & $8.96(7.97-8.96)^{\mathrm{a}}$ & $7.97(5.97-8.96)^{\mathrm{a}}$ & $6.97(2.98-8.96)^{\mathrm{b}}$ & 0.048 \\
\hline & & VAC & $8.96(3.98-8.96)^{\mathrm{a}}$ & $6.97(2.98-8.96)^{\mathrm{ab}}$ & $6.97(5.9-8.96)^{b}$ & 0.013 \\
\hline & \multirow{2}{*}{ BRSV } & NVAC & $2.98(0.99-4.0)$ & $2.98(0.99-2.98)$ & $1.49(0.00-2.98)$ & 0.096 \\
\hline & & VAC & $2.98(0.99-5.97$ & $1.99(0.00-3.98)$ & $1.99(0.00-3.98)$ & 0.150 \\
\hline & \multirow{2}{*}{ BPI3V } & NVAC & $4.98(3.98-7.97)^{\mathrm{a}}$ & $6.97(5.97-8.96)^{\mathrm{b}}$ & $5.48(3.98-9.96)^{\mathrm{ab}}$ & 0.002 \\
\hline & & VAC & $5.97(2.98-7.97)^{\mathrm{a}}$ & $6.97(5.97-9.96)^{\mathrm{b}}$ & $5.97(5.97-8.96)^{\mathrm{c}}$ & 0.000 \\
\hline \multirow{12}{*}{ 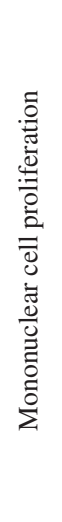 } & \multirow{2}{*}{ Control } & NVAC & $0.58 \pm 0.51$ & $0.84 \pm 0.66$ & $1.04 \pm 0.87$ & 0.607 \\
\hline & & VAC & $0.51 \pm 0.25^{\mathrm{a}}$ & $1.23 \pm 0.94^{\mathrm{b}}$ & $1.8 \pm 0.55^{\mathrm{c}}$ & 0.000 \\
\hline & \multirow{2}{*}{ ConA } & NVAC & $2.11 \pm 0.74$ & $2.43 \pm 0.56$ & $1.88 \pm 0.37$ & 0.200 \\
\hline & & VAC & $2.22 \pm 0.52^{\mathrm{ab}}$ & $2.31 \pm 0.4^{\mathrm{a}}$ & $1.85 \pm 0.29^{b}$ & 0.008 \\
\hline & \multirow{2}{*}{ BVDV-1 } & NVAC & $1.41 \pm 0.7$ & $1.62 \pm 0.56$ & $1.64 \pm 0.42$ & 0.658 \\
\hline & & VAC & $1.6 \pm 0.61^{\mathrm{ab}}$ & $2.02 \pm 0.66^{\mathrm{a}}$ & $1.39 \pm 0.57^{\mathrm{b}}$ & 0.026 \\
\hline & \multirow{2}{*}{ BVDV-2 } & NVAC & $1.24 \pm 0.76$ & $1.09 \pm 0.94$ & $1.05 \pm 0.7$ & 0.607 \\
\hline & & VAC & $1.33 \pm 0.58$ & $0.97 \pm 0.56$ & $1.02 \pm 0.62$ & 0.607 \\
\hline & \multirow{2}{*}{ Hobi-like } & NVAC & $1.64 \pm 0.51^{\mathrm{a}}$ & $2.03 \pm 0.45^{\mathrm{a}}$ & $1.53 \pm 0.33^{\mathrm{a}}$ & 0.077 \\
\hline & & VAC & $1.71 \pm 0.61^{\mathrm{ab}}$ & $2.09 \pm 0.6^{\mathrm{a}}$ & $1.53 \pm 0.41^{\mathrm{b}}$ & 0.026 \\
\hline & \multirow{2}{*}{ BoHV-1 } & NVAC & $0.65 \pm 0.36$ & $0.97 \pm 1.08$ & $0.44 \pm 0.24$ & 0.321 \\
\hline & & VAC & $0.85 \pm 0.63$ & $0.54 \pm 0.53$ & $0.57 \pm 0.36$ & 0.276 \\
\hline
\end{tabular}

$\mathrm{T}=$ times; $P=$ comparison between times (Friedman test). Different lowercase letters on the same line indicate differences between the moments by the Wilcoxon test. Significance was considered when $P \leq 0.05$.

Medians of antibody titers against BoHV-1 decreased between T1 and T3 in NVAC $(P=0.048)$ and VAC groups $(P=0.013)$. Multiple comparisons between times revealed differences between $\mathrm{T} 1$ and $\mathrm{T} 3$
$(P=0.027)$ and T2 and T3 $(P=0.049)$ in NVAC group. In VAC group the differences were detected between $\mathrm{T} 1$ and $\mathrm{T} 3(P=0.032)$, in addition to seroconversion of 2 calves in $\mathrm{T} 2(11.11 \%, 2 / 18)$ and 3 calves in $\mathrm{T} 3$ 
$(16.66 \%, 3 / 18)$. For BRSV, a tendency for a decrease in antibodies titers was observed over time but only in NVAC group $(P=0.096)$. Therefore, values obtained in the VAC group were constant over time $(P=0.150)$. Seroconversion of one calf $(10 \%, 1 / 10)$ was detected at $\mathrm{T} 2$ in NVAC group, and one calf at T2 and one at T3 $(5.55 \%, 1 / 18)$ from VAC group. Titers of antibodies for BPI3V varied over time in both experimental groups $(\mathrm{NVAC}=0.002 ; \mathrm{VAC}=0.000)$. Multiple comparisons over time revealed differences between T1 and T2 $(P$ $=0.007)$ and a trend between T2 and T3 $(P=0.073)$ in NVAC; and between T1 and T2 $(P=0.002), \mathrm{T} 1$ and T3 $(P=0.032)$, and between T2 and T3 $(P=0.042)$ in the VAC group. Seroconversion was detected in 3 calves from NVAC $(30 \%, 3 / 10)$ at $\mathrm{T} 2$ and in 6 calves $(33 \%, 6 / 18)$ from VAC at T2.

Means and standard deviations of MN cells proliferation are shown in Table 2. The spontaneous proliferation of unstimulated $\mathrm{MN}$ was greater in the VAC group at D56 $(P=0.047)$. The analysis over time by Friedman test showed an increase proliferation of MN cells throughout the experiment only in the VAC group (NVAC, $P=0.607$; VAC, $P=0.000$ ). Multiple comparisons using the Wilcoxon test detected differences between D14 and D35, and D14 and D56 ( $P=$ 0.004 and $P=0.001$, respectively), and a trend between D35 and D56 $(P=0.088)$.

Cells stimulated with ConA, BVDV-1, BVDV2, BVDV-3, and BoHV-1 did not show differences between groups throughout the study $(P \geq 0.05)$. Time analysis showed variations in the proliferative response of MN cells stimulated with ConA (NVAC, $P$ $=0.200$ and VAC, $P=0.008$ ), BVDV-1 (NVAC, $P=$ 0.658 and VAC, $P=0.026$ ), and BVDV-3 (NVAC, $P$ $=0.077$; VAC, $P=0.026)$ in the VAC group. Multiple comparisons over time revealed differences between $\mathrm{T} 2$ and T3 for ConA $(P=0.01)$; BVDV-1 $(P=0.025)$, and BVDV-3 $(P=0.025)$.

Regarding BVDV-2 and BoHV-1, it was not possible to detect variations over time for NVAC ( $P$ $=0.607$ and $P=0.321)$ or VAC group $(P=0.607$ and $P=0.276)$.

\section{DISCUSSION}

This research evaluated the influence of early vaccination against respiratory viruses on the prevalence of BRD, leukogram, and specific immune response of Holstein heifers.
Due to the high prevalence observed between 30 and 60 days of life, our findings suggested early BRD infections presented in both experimental groups. A large survey demonstrated similar results with incidence of BRD around 22\% (630/2874) in the first 3 months of life of the calves, with most animals being treated around 30 days of age [23].

According to the Dairy Calf and Heifer Association, the occurrence of BRD should be less than $10 \%$ in the pre-weaning period (1 to 60 days of life), but we can see a large gap between the goal and the reality. These data together reinforce the importance of efficient protocols for early immunization before the maximum peak of the disease, especially in colder months of the year in the southern and southeastern regions of Brazil, where the temperatures are below the interval between 15 and $25^{\circ} \mathrm{C}$ characterized as a thermoneutral zone of the calves [19].

Far beyond the vaccination protocols, management practices and facilities are also factors that influenced the high prevalence of BRD reported in this research, since these factors are practically uncontrollable in a study carried out in the field. The present research was carried out in a commercial farm with intensive calf rearing in individual suspended housing. The intensification of calf production in a small area with low ceilings has a negative effect on ventilation, insolation of the area, and air quality. In addition, the change of beds was carried out only once a week in our study. The management practices such as living with older calves (odds ratio $=3.21$ ), the presence of a damp bed, and the use of maternity for activities other than parturition (odds ratio $=2.61$ ) were responsible for the increasing prevalence of BRD in calves grouped and fed with automatic feeders [13].

The present study did not demonstrate the effect of early parenteral vaccination on the prevalence of BRD. In one field survey, vaccination of calves between 2 and 5 weeks of life was not associated with decreased incidence or mortality from BRD, or with growth rates up to 3 months of age [24].

Despite the clear absence of differences between the prevalence of BRD in both groups, it was possible to observe a greater number of leukocytes and neutrophils in T2 (D35) and T3 (D56) in the NVAC group, pointing to greater intensity of the inflammatory response in these animals in the face of the multiple natural challenges. This fact also reflected in 
the leukocyte profile over time, observing the classic decrease with age in the number of total leukocytes and neutrophils only in the VAC group [4]. The inflammatory leukocyte profile also explains the higher $\mathrm{Hp}$ values observed in the NVAC group at T2, despite the absence of statistical differences between the groups.

There are no national data about the efficacy of parenteral vaccines in the humoral and cellular immune response in calves in the neonatal phase, despite the high occurrence of BRD between 30 and 60 days of life. Among the commercial injectable vaccines available in Brazil, we chose a formulation that stimulates the best humoral immune response against BVDV and BoHV-1 in animals with 8 and 12 months of age [1]. The selected vaccine contained an ISCOM (Immunestimulating Complexes) and their adjuvants form nanoparticles similar to spherical capsules composed of cholesterol, amphigen, and saponin derivatives (Quil A). The ISCOM is a potent adjuvant which induces more generalized immune response, including delayed hypersensitivity response, increased serum $\operatorname{IgG} 1$ and IgG2a, increased IgA secretion in the intestinal mucosa, and production of Th1 and Th2 adaptive response dependent on cytokines [2].

The titers of antibodies against BVDV, BoHV1, and BRSV were similar between the groups, although the VAC calves showed higher medians of the antibodies for all respiratory viruses after the booster (D56). The absence of differences between groups may indicate that vaccination of calves at 14 days of age did not induce humoral immune response to these viruses. The interference of maternal antibodies in the humoral immune response induced by vaccination has been presented in several publications over time $[6,8,25]$. Antibodies titers decreased over time, due to the half-life of approximately 23, 21, 36, and 30 days for the specific maternal antibodies found for BVDV, BoHV-1, BRSV, and BPI3V, respectively [8].

The prevalence observed for BRD between D30 and D60 in both groups indicates natural exposure to respiratory agents and can be justified by the high degree of dissemination of virus by air and the circulation of employees between different areas of the farm. Natural infections were suggested in the NVAC group by the presence of BVDV, BRSV, and BPI3V antibodies in D35, probably due to the association between exposure and vaccine response. Despite the absence of differences between specific titers of antibodies in both groups, it could be noted that the VAC group showed greater oscillations in time for the titers of antibodies against BVDV-1 and BPI3-V with a peak at D35.

The primary vaccination probably generated some cellular memory and humoral immune response of greater intensity in the presence of natural challenges to respiratory pathogens. This may explain the lower intensity of inflammatory response in the VAC group after the booster. Other factors in addition to the interference of maternal antibodies must be considered in the response to early vaccination. In relation to BVDV, it is known that inactive vaccines induce an immune response of low intensity and duration [12]. Therefore, comparison of Brazilian researches and international data with modified live vaccines is limited.

Regarding to BoHV-1, there was a mild humoral immune response after vaccinations with a formulation containing the modified live and thermosensitive virus, considering the slight decrease in antibodies over time only in the VAC group. It was demonstrated the interference of maternal antibodies on the vaccine response induced by live-modified BoHV-1 [8]. Considering BRSV, low titers of antibodies were observed in both groups, but the VAC group showed stability in titers concentrations between D14 to D56. These absence of differences can be interpreted as ineffectiveness of the vaccine; however previous research has demonstrated protection against acute clinical disease caused by BRSV in the absence of seroconversion after vaccination in calves with high titers of maternal antibodies [21]. Potentially calves with circulating maternal antibodies can develop virus-specific $\mathrm{T}$ cell responses [6]. BRSV has the particularity of inducing short-term immune memory [10].

Cellular immune response evaluated by the proliferation of $\mathrm{MN}$ cells stimulated with BVDV-1, BVDV-2, BVDV-3 (Hobi-like), and BoHV-1 strains was similar between the groups. Woolums et al. [25] also found no differences in the intensity of the cellular immune response in beef calves vaccinated with a dose of injectable or intranasal vaccine at 14 days of age compared to the NVAC group. In the abovementioned research, MN were stimulated with BoHV-1, BVDV, BRSV, and Pasteurella multocida. The cellular immune response was evaluated by the detection of $\mathrm{CD} 25^{+}$cells, production of IFN-gamma, and proliferative response. At the time of this study, Brazil did not have yet an intranasal vaccine against BRD as recently. The use 
of this vaccine in the first week of life and around weaning is already a reality on dairy farms, although further studies similar to Woolums et al. [25] for the use in the field are needed.

Endsley et al. [7] analyzed three experimental groups: G1- calves primovaccinated with 7 weeks of age with BVDV-1 and BVDV-2 live and modified; G2- calves primovaccinated with 7 weeks of age with inactivated BVDV-1 and BVDV-2; G3- non-vaccinated control calves. There was no vaccination booster after the first dose in both groups of vaccinated calves. The authors also did not observe evidence of the induction of the humoral immune response after vaccination, however they found a higher proportion of lymphocytes expressing the CD25 marker in G1, after culturing the mononuclear cells stimulated with the BVDV-1 and BVDV-2 strains. The authors did not prove cellular immune response in the $\mathrm{G} 2$ and $\mathrm{G} 3$, which is consistent with the findings of this research, even considering the younger animals included by our team.

Commercial vaccines with live modified BVDV were not a reality in Brazil during the time that this research was carried out. There is currently a monovalent vaccine on the market and some formulations are being registered. The use of live modified vaccines can be a tool to induce cellular immune response in young calves, but it must be validated for Brazilian conditions [7].

We cannot fail to report that in this study, the proliferation of non-challenged cells was greater in the VAC group, in addition to the greater intensity of proliferative response when $\mathrm{MN}$ cells were stimulated with BVDV-1 and Hobi-like around the peak of BRD. This fact may suggest the production of cellular memory after the first vaccination of the calves, when cells with a Th2 profile mainly produce IL-4, IL-5, and IL-6 cytokines. The IL- 4 is able to induce the activation of B lymphocytes, which undergo clonal expansion and differentiate into memory cells or mature plasma cells [5]. The fact that the VAC group had previous contact with the antigens corroborates to the greater intensity of cell proliferation.

In general, this research showed evidence that the early vaccination of calves contributed to the lower occurrence of respiratory disease under natural challenges provided by an environment full of risk factors in the field. The subtle differences observed between the experimental groups demonstrated lower intensity of the inflammatory process in the phase of greater occurrence of BRD, higher titers of antibodies against BPI3V after booster, lower frequency of seroconversion against BoHV-1, and stability in the titers of antibodies against BRSV presented in calves vaccinated at 14 days of age.

\section{CONCLUSIONS}

Despite the partial efficacy of the parenteral vaccination against the respiratory viruses observed in calves vaccinated around 14 days of age, it can be concluded that the decrease in the intensity of the inflammation and the higher antibodies against BPI3V estimulated cellular memory and humoral immune response to greater intensity when compared to unvaccinated calves. Such factors may contribute positively to heifers to face the natural exposure to the respiratory viruses and the additional environmental and management risk factors presented in the dairy farms.

\section{MANUFACTURERS}

${ }^{1}$ Zoetis. São Paulo, SP, Brazil.

${ }^{2}$ Mindray do Brasil. São Paulo, SP, Brazil.

Funding. This research was supported by grants from Fundação de Amparo à Pesquisa do Estado de São Paulo (FAPESP; Project number 2012/02129-8 and 2013/050604-0).

Ethical approval. The Animal Ethics Committee of the Faculty of Veterinary Medicine and Animal Science of the University of São Paulo - FMVZ/USP approved this research (protocol \# 2574/2013).

Declaration of interest. The authors report no conflicts of interest. The authors alone are responsible for the content and writing of paper.

\section{REFERENCES}

1 Anziliero D., Martins M., Weiss M., Monteiro F.L., Ataide C.F., Weiblen R. \& Flores E.F. 2015. Resposta sorológica aos herpesvírus bovino tipos 1 e 5 e vírus da diarreia viral bovina induzida por vacinas comerciais. Ciencia Rural. 45(1): 58-63.

2 Beacock-Sharp H., Donachie A.M., Robson N.C. \& Mowat A.M. 2003. A role for dendritic cells in the priming of antigen-specific $\mathrm{CD} 4^{+}$and $\mathrm{CD} 8{ }^{+} \mathrm{T}$ lymphocytes by immune-stimulating complexes in vivo. International Immunology. 15(6): 711-720. 
3 Brasil. 2017. Lista de produtos registrados, lista cronológica de análise de registro inicial e atos da CPV, 2017. Disponível em: < http://www.agricultura.gov.br/assuntos/insumos-agropecuarios/insumos-pecuarios/produtos-veterinarios/ arquivos-comunicacoes-e-instrucoes-tecnicas/lista-de-produtos-registrados-lista-cronologica-de-analise-de-registroinicial-e-atos-da-cpv.xlsx>. [Accessed online in November 2019].

4 Brun-Hansen H.C., Kampen A.H. \& Lund A. 2006. Hematologic values in calves during the first 6 months of life. Veterinary Clinical Pathology. 35(2): 182-187.

5 Chase C.C.L., Hurley D.J. \& Reber A.J. 2008. Neonatal immune development in the calf and its impact on vaccine response. Veterinary Clinics of North America. Food Animal Practice. 24(1): 87-104.

6 Ellis J., West K., Cortese V. \& Weigel D. 2001. Effect of maternal antibodies on induction and persistence of vaccineinduced immune responses against bovine viral diarrhea virus type II in young calves. Journal of American Veterinary Medical Association. 219(3): 351-356.

7 Endsley J. J., Roth J.A., Ridpath J. \& Neill J. 2003. Maternal antibody blocks humoral but not $\mathrm{T}$ cell responses to BVDV. Biologicals. 31(2): 123-125.

8 Fulton R.W., Briggs R.E., Payton M.E., Confer A.W., Saliki J.T., Ridpath J.F., Burge L.J. \& Duff G.C. 2004. Maternally derived humoral immunity to bovine viral diarrhea virus (BVDV)1a, BVDV1b, BVDV2, bovine herpesvirus-1, parainfluenza-3 virus, bovine respiratory syncytial virus, Mannheimia haemolytica and Pasteurella multocida in beef calves, antibody decline by half-life studies and effect on response to vaccination. Vaccine. 22(5): 643-649.

9 Godden S.M., Lombard J.E. \& Woolums A.R. 2019. Colostrum management for dairy calves. Veterinary Clinics of North America. Food Animal Practice. 35(3): 535-556.

10 Guzman E. \& Taylor G. 2015. Immunology of bovine respiratory syncytial virus in calves. Molecular Immunology. 66(1): 48-56.

11 Jones G.E. \& Mould D.L. 1984. Adaptation of the guaiacol (peroxidase) test for haptoglobins to a microtitration plate system. Research in Veterinay Science. 37(1): 87-92.

12 Lima M.D., Vogel F.S.F., Flores E.F. \& Weiblen R. 2005. Anticorpos neutralizantes contra o vírus da Diarréia Viral Bovina (BVDV): comparação entre um imunógeno experimental atenuado e três vacinas comerciais inativadas. Ciência Rural. 35(1): 230-234.

13 Medrano-Galarza C., LeBlanc S.J., Jones-Bitton A., DeVries T.J., Rushen J., Marie de Passillé A., Endres M.I. \& Haley D.B. 2018. Associations between management practices and within-pen prevalence of calf diarrhea and respiratory disease on dairy farms using automated milk feeders. Journal of Dairy Science. 101(3): 2293-2308.

14 Morita L.M. 2020. Development of innate immune response in healthy Holstein calves from birth until weaning. 73f. São Paulo, SP. Dissertação (Mestrado em Ciências) - Programa de Pós-Graduação em Clínica Veterinária, Universidade de São Paulo.

15 Novo S.M.F., Costa J.F.R., Baccili C.C., Sobreira N.M., Silva B.T., Oliveira P.L., Hurley D.J. \& Gomes V. 2017. Effect of maternal cells transferred with colostrum on the health of neonate calves. Research in Veterinary Science. 112: 97-104.

16 OIE. 2016. Manual of diagnostics tests and vacines for terrestrial animals. Disponível em:<http://wwwoieint/en/ international-standard-setting/terrestrial-manual/access-online/> [Accessed online in March 2014].

17 Platt R., Widel P.W., Kesl L.D. \& Roth J.A. 2009. Comparison of humoral and cellular immune responses to a pentavalent modified live virus vaccine in three age groups of calves with maternal antibodies, before and after BVDV type 2 challenge. Vaccine. 27(33): 4508-4519.

18 Poulsen K.P. \& McGuirk S.M. 2009. Respiratory disease of the bovine neonate. Veterinary Clinics of North America. Food Animal Practice. 25(1): 121-137.

19 Roland L., Drillich M., Klein-Jöbstl D. \& Iwersen M. 2016. Invited review: influence of climatic conditions on the development, performance, and health of calves. Journal of Dairy Science. 99(4): 2438-2452.

20 Silva B.T., Baccili C.C., Henklein A., Oliveira P.L., Oliveira S.M.F.N., Sobreira N.M., Ribeiro C.P. \& Gomes V. 2018. Transferência de imunidade passiva (TIP) e dinâmica de anticorpos específicos em bezerros naturalmente expostos para as viroses respiratórias. Arquivo Brasileiro de Medicina Veterinária e Zootecnia. 70(5): 1414-1422.

21 Van der Sluijs M.T., Kuhn E.M. \& Makoschey B. 2010. A single vaccination with an inactivated bovine respiratory syncytial virus vaccine primes the cellular immune response in calves with maternal antibody. BMC Veterinary Research. 6(1): 2-7. 
22 Windeyer M.C. \& Gamsjäger L. 2019. Vaccinating calves in the face of maternal antibodies: challenges and opportunities. Veterinary Clinics of North America. Food Animal Practice. 35(3): 557-573.

23 Windeyer M.C., Leslie K. E., Godden S.M., Hodgins D.C., Lissemore K.D. \& LeBlanc S.J. 2014. Factors associated with morbidity, mortality, and growth of dairy heifer calves up to 3 months of age. Preventive Veterinary Medicine. 113(2): 231-240.

24 Windeyer M.C., Leslie K.E., Godden S.M., Hodgins D.C., Lissemore K.D. \& LeBlanc S.J. 2015. Association of bovine respiratory disease or vaccination with serologic response in dairy heifer calves up to three months of age. American Journal of Veterinary Research. 76(3): 239-245.

25 Woolums A.R., Berghaus R.D., Berghaus L.J., Ellis R.W., Pence M.E., Saliki J.T., Hurley K.A., Galland K.L., Burdett W.W., Nordstrom S.T. \& Hurley D.J. 2013. Effect of calf age and administration route of initial multivalent modified-live virus vaccine on humoral and cell-mediated immune responses following subsequent administration of a booster vaccination at weaning in beef calves. American Journal of Veterinary Research. 74(2): 343-354. 